\title{
Clinical profile and outcome of acute organophosphate poisoning in children of Upper Egypt: a cross-sectional study
}

\author{
Khaled A. Abdel Baseer ${ }^{1 *}$ D, Eman Fathala Gad ${ }^{2}$ and Yaser F. Abdel Raheem²
}

\begin{abstract}
Background: Organophosphates are one of the most common agents of poisoning in developing countries including Egypt. Due to lack of data about characteristics of organophosphates poisoning in our localities, we aimed to evaluate its clinical pattern and factors affecting outcome.
\end{abstract}

Methods: It was a cross-sectional study conducted in South valley University hospital between January 2019 and December 2019. It included all children $\leq 16$ years of age presented with organophosphates poisoning. Diagnosis was performed from the history taken from the patient's relatives and presenting symptoms. Demographic data, mode and route of poisoning, time from exposure to presentation, clinical symptomatology, grading and routine investigations were evaluated in addition to treatment taken and outcome.

Results: During the study period, 108 children; mean age was $7.95 \pm 4.11$ years (range 1. 5-16 years) presented with organophosphorous poisoning. Sixty five (60\%) cases were females and $43(40 \%)$ were males. Unintentional acts (87\%) were detected more than suicidal (13\%) and inhalation route (63.8\%) more than ingestion (36. 2\%). Miosis was the most frequent clinical sign (100\%) followed by respiratory distress (77.7\%). Regarding time of presentation to emergency department, $43(40 \%)$ cases were presented within $6 \mathrm{~h}$ while others presented more than $6 \mathrm{~h}$ postexposure. Mechanical ventilation (MV) was needed for 14 (13\%) cases and 6 (5.5\%) cases died due to respiratory failure. Duration of hospital stay, mean time interval from toxic exposure to hospital presentation, leucocytosis, need for MV and cumulative dose of pralidoxime were significantly higher in non survivors than survivors while Pao2 (partial arterial oxygen) and GCS (Glasgow coma scale) were significantly lower.

Conclusion: This study concluded that time consumed till presentation to hospital, low GCS, need for MV, leucocytosis, decreased $\mathrm{PaO} 2$ and increased cumulative dose of pralidoxime were independent risk factors of mortality.

Keywords: Organophosphates poisoning, Mortality, Pattern, Outcome

\footnotetext{
* Correspondence: Khaledabdalla20@yahoo.com

'Department of Pediatrics, Qena Faculty of Medicine, South Valley University, Qena, Egypt

Full list of author information is available at the end of the article
}

(C) The Author(s). 2021 Open Access This article is licensed under a Creative Commons Attribution 4.0 International License, which permits use, sharing, adaptation, distribution and reproduction in any medium or format, as long as you give appropriate credit to the original author(s) and the source, provide a link to the Creative Commons licence, and indicate if changes were made. The images or other third party material in this article are included in the article's Creative Commons licence, unless indicated otherwise in a credit line to the material. If material is not included in the article's Creative Commons licence and your intended use is not permitted by statutory regulation or exceeds the permitted use, you will need to obtain permission directly from the copyright holder. To view a copy of this licence, visit http://creativecommons.org/licenses/by/4.0/ The Creative Commons Public Domain Dedication waiver (http://creativecommons.org/publicdomain/zero/1.0/) applies to the data made available in this article, unless otherwise stated in a credit line to the data. 


\section{Background}

Organophosphate compounds (OPCs) are acetylcholinesterase (AChE) inhibitors used as pesticides with a potential for induction of systemic illness upon toxic exposure [1, 2]. Due to their easy availability and low cost, organophosphates are one of the most common causes of poisoning in the world from agricultural, unintentional, or suicidal exposure [3]. These compounds enter the human body by ingestion, inhalation or skin absorption, and irreversibly inhibit AChE that is responsible for degradation of acetylcholine (Ach) [4, 5]. Accumulation of Ach activates muscarinic and nicotinic receptors at synapses within the peripheral and central nervous systems producing neurotoxic sequelae with a high mortality rate [6]. The initial management of acute OP poisoning includes cardio-respiratory stabilization and decontamination including removing clothes (a possible source of continued exposure), washing of skin and eyes, and consideration of gastric lavage and activated charcoal [7]. Atropine which is peripheral and central muscarinic receptor antagonist as well as pralidoxime chloride, which reactivates inhibited AChE are the mainstay of treatment [8]. Most deaths occur due to respiratory and cardiovascular failure, respiratory muscles paralysis and obstruction caused by bronchial secretions and OP induced bronchospasm [9]. Due to paucity of research on the clinical characteristics and outcome of poisoning in children of our region, this study was conducted with the aim of evaluating clinical pattern and risk factors of mortality by organophosphates poisoning.

\section{Methods}

It was a cross-sectional study conducted in South valley University hospital, Egypt between January 2019 and December 2019. It included all children $<16$ years of age presenting to emergency and intensive care units with organophosphate poisoning. Data was collected from parents or care-givers using a pre-determined questionnaire (Additional file 1). The baseline demographics including age, gender and residence in addition to clinical data were recorded for all recruited patients. Detailed history and basic information related to circumstances of poisoning were taken including mode of poisoning, time of exposure, reason of poisoning, type of poison and poisoning route. The symptoms with which the patients presented were recorded and detailed clinical examination including Glasgow coma scale (GCS) was done. On admission to the Emergency Department, clinical classification and grading of organophosphorous poisoning as estimated by Bardin et al. [10], was used for evaluation of intoxication. They classify cases into grade 1 as having hypersecretion, fasciculations and conscious, grade 2 as Grade 1 with hypotension but unconscious and Grade 3 as Grade 2 with stupor, abnormal chest $\mathrm{x}$ - ray and $\mathrm{paO} 2<10 \mathrm{mmHg}$. This grading is of great value in recognition of severely intoxicated children who need rapid admission to the intensive care unit. Generally, as our rural locality depends mainly on agriculture, organophosphate compounds are in common use and frequently found in the home.

Poisoned cases are usually diagnosed on the basis of history of exposure or contact and characteristic clinical picture specially presence of pin point pupil, excessive chest secretions and distinct garlic odor of the patient's breath and vomits that characterize most of these compounds. In doubtful cases, a therapeutic trial of atropine is employed, with a good response to atropine supporting the diagnosis. However, In our population, the bottle of consumed OP compound often accompanies the patient to the Emergency Department. If a patient did not present with a clinical history or clinical features consistent with OP poisoning, they were excluded from the study.

Baseline investigations included complete blood count, urea, creatinine and arterial blood gas values. After diagnosis, patients underwent immediate assessment and care of airway, breathing, and circulation and those admitted with ingestion were subjected to gastric lavage followed by repeated doses of activated charcoal. In those of inhalation and dermal exposure, all the clothes were replaced and the skin washed with water and soap. All patients were given atropine initially $0.02 \mathrm{mg} / \mathrm{kg}$ intravenously. The main end points of atropinization were a clear chest on auscultation with resolution of crepitations and wheeze and a heart rate more than 80 beats/min. If these targets were not achieved by 3-5 minutes, we doubled the intravenous dose continuously every 3-5 minutes until atropinization had been achieved.

Due to its high cost, pralidoxime is generally reserved for patients with evidence of severe nicotinic receptor stimulation such as muscle fasciculations and progressive muscle weakness. It was administered as loading dose of $30 \mathrm{mg} / \mathrm{kg}$ IV over 30 minutes (maximum $1 \mathrm{~g}$ ), followed by an infusion of $10 \mathrm{mg} / \mathrm{kg} / \mathrm{h}$ (maximum rate $650 \mathrm{mg} / \mathrm{hr}$ ) for 2-4 days. Atropine was used at same time with pralidoxime. The institutional ethics committee of South valley University approved the study and parents provided informed consent.

\section{Statistical analyses}

Statistical analyses of the data collected from the two outcome groups (survivors and non survivors) were compared using SPSS version 20 for Windows (Chicago, IL. USA). Continuous variables were expressed as mean \pm standard deviation, and categorical variables were expressed as frequency. Fisher exact test 
was used examine the relation between qualitative variables and t-test used for comparison of means. Linear regression analysis was used to study significant predictors of outcome. A p value $<0.05$ was considered statistically significant.

\section{Results}

Sociodemographic and laboratory characteristics of studied patients were summarized in Table 1 . The mean age of patients was $7.95 \pm 4.11$ years (range 1. 5-16 years). Sixty five $(60 \%)$ children were females with female to male ratio of 1.5: 1 . Unintentional acts were more than suicidal and poisoning by inhalation route more than by ingestion. Exposure patterns showed that spraying for pest control in the field was the most frequent source followed by lotions used for treatment of head lice that are usually home made using OPC. Mean time (hours) from poisoning exposure to emergency unit presentation was $6.06 \pm 3.12$ (range 1-36 hours) and mean duration (days) of hospital stay was $3.51 \pm 1.75$ days (range 2-10 days). Of the known documented (96) cases, most poisonings were by malathion (75\%), followed by Chlorpyrifos $(8.3 \%)$ and diazinon (4. $2 \%)$. Mortality rate was $5.5 \%$ due to respiratory failure. Table 2 compares poisoned children according to mode of intoxication. Suicidal attacks were significantly more common in older children and females. Duration of hospital stay was significantly more prolonged with suicidal attempts. Clinical and therapeutic features of patients were shown in Table 3 . Forty three $(40 \%)$ cases were severely poisoned and $29(26.8 \%)$ were in deep coma. Miosis was the most common clinical feature $(100 \%)$ followed by respiratory distress (77.7\%), vomiting (43.5\%) and bradycardia (33. $3 \%)$. The most commonlyencounteredcomplications were respiratory failure (13\%) followed by aspiration pneumonia (4.6\%). Mechanical ventilation was needed in $14(13 \%)$ cases due to respiratory failure. All patients were given atropine initially at emergency department (0. 2-0.8mg) with cumulative dose $1.33 \pm 0.52 \mathrm{mg}$. Pralidoxime chloride was used in 9 cases only initially at emergency department $(0.5-1 \mathrm{gm})$ with cumulative dose $13.95 \pm 5.04 \mathrm{gm}$. Table 4 compares poisoned patients according to outcome. Duration of hospital stay, mean time interval from toxic exposure to hospital presentation, leucocytosis and need for mechanical ventilation were significantly higher in non survivors than survivors. On the other hand, Pao2 and GCS were significantly lower in non survivors. Mortality was more with Chlorpyrifos followed by diazinon and least with malathion. Multivariate regression analyses (Table 5) revealed that time consumed till presentation to hospital, low GCS, need for $\mathrm{MV}$, leucocytosis, decreased $\mathrm{PaO} 2$ and increased cumulative dose of pralidoxime were independent risk factors of mortality.
Table 1 Demographic and laboratory characteristics of studied patients

\begin{tabular}{|c|c|}
\hline Variable & $\begin{array}{l}\text { Total patients }=108 \\
\text { Mean } \pm \text { SD } / n(\%)\end{array}$ \\
\hline Age (years) & $7.95 \pm 4.11$ \\
\hline \multicolumn{2}{|l|}{ Sex } \\
\hline Male & $43(40 \%)$ \\
\hline Female & $65(60 \%)$ \\
\hline \multicolumn{2}{|l|}{ Residence } \\
\hline Urban & $35(32.5 \%)$ \\
\hline Rural & $73(67.5 \%)$ \\
\hline \multicolumn{2}{|l|}{ Mode of poisoning } \\
\hline Unintentional & $94(87 \%)$ \\
\hline Suicidal & $14(13 \%)$ \\
\hline \multicolumn{2}{|l|}{ Route of poisoning } \\
\hline Inhalation & $69(63.8 \%)$ \\
\hline Ingestion & 39 (36. 2\%) \\
\hline \multicolumn{2}{|l|}{ Identifiable sources of poisoning } \\
\hline Exposure in agriculture field & $41(38 \%)$ \\
\hline Lotion for head lice & $33(30.5 \%)$ \\
\hline Surface \& room sprays & $20(18.5 \%)$ \\
\hline Spray for house insects & $14(13 \%)$ \\
\hline \multicolumn{2}{|c|}{ Type of poisoned organophosphate } \\
\hline Malathion & $81(75 \%)$ \\
\hline Chlorpyrifos & $9(8.3 \%)$ \\
\hline Diazinon & $6(5.5 \%)$ \\
\hline Unknown & $12(11.2 \%)$ \\
\hline \multicolumn{2}{|l|}{ Outcome } \\
\hline Improved & $102(94.5 \%)$ \\
\hline Expired & $6(5.5 \%)$ \\
\hline \multicolumn{2}{|l|}{ Blood picture } \\
\hline Hemoglobin, g/dL & $10.14 \pm 1.52$ \\
\hline Leucocytes, $\times 10^{3} / \mathrm{mL}$ & $10.56 \pm 3.24$ \\
\hline Platelets $\times 10^{3} / \mathrm{mL}$ & $310.11 \pm 89.20$ \\
\hline \multicolumn{2}{|l|}{ Blood gases } \\
\hline $\mathrm{PaO} 2 \mathrm{mmHg}$ & $96.46 \pm 11.48$ \\
\hline $\mathrm{PaCO} 2 \mathrm{mmHg}$ & $40.21 \pm 3.87$ \\
\hline Duration of hospital stay (days) & $3.51 \pm 1.75$ \\
\hline Time to presentation (hours) & $6.06 \pm 3.12$ \\
\hline Glasgow coma scale & $($ Median $=13, I Q R=7)$ \\
\hline
\end{tabular}

$\mathrm{PaO} 2$ Partial pressures of oxygen, $\mathrm{PaCO} 2$ Partial pressures of carbon dioxide, IQR Interquartile range

\section{Discussion}

Organophosphates poisoning (OP) is a major health problem all over the world, particularly in the developing countries due to widespread usage and application of pesticides in agricultural and environmental pest control 
Table 2 Comparison between studied cases according to mode of poisoning

\begin{tabular}{|c|c|c|c|}
\hline Variables & $\begin{array}{l}\text { Unintentional } \\
N=94\end{array}$ & $\begin{array}{l}\text { Suicidal } \\
N=14\end{array}$ & $P$ value \\
\hline \multicolumn{4}{|l|}{ Age (years) } \\
\hline$\leq 6$ years $(n=46)$ & $46(48.9 \%)$ & $0(0 \%)$ & $<0.001$ \\
\hline$>6-<12$ years $(n=27)$ & $27(28.7 \%)$ & $0(0 \%)$ & \\
\hline$\geq 12$ years $(n=35)$ & $21(22.4 \%)$ & $14(100 \%)$ & \\
\hline \multicolumn{4}{|l|}{ Sex } \\
\hline Males $(n=43)$ & $41(43.6 \%)$ & $2(14.3 \%)$ & $<0.05$ \\
\hline Females $(n=65)$ & $53(56.4 \%)$ & $12(85.7 \%)$ & \\
\hline \multicolumn{4}{|l|}{ Residence } \\
\hline Urban $(n=35)$ & $29(30.9 \%)$ & $6(42.9 \%)$ & NS \\
\hline Rural $(n=73)$ & $65(69.1 \%)$ & $8(57.1 \%)$ & \\
\hline Need for mechanical ventilation & $10(10.6 \%)$ & $4(28.6 \%)$ & NS \\
\hline Duration of hospital stay (days) & $3.24 \pm 1.59$ & $5.35 \pm 1.73$ & $<0.01$ \\
\hline Mortality & $4(4.3 \%)$ & $2(14.3 \%)$ & NS \\
\hline
\end{tabular}

NS Non significant; $P$ value $<0.05$ is significant

[11]. Easy availability and excessive popularity of its use as insecticides and pesticides has increased the incidence of ingestion, resulting in increasing suicidal and unintentional poisoning [12]. In the present study, the majority of organophosphates poisoning occurred due to unintentional ingestion or inhalation specially in young children. Therefore, it can be reduced through use of effective preventive measures and community health education.

Females showed an evident preponderance over males with male: female ratio of $1: 1.5$. This finding was in agreement with studies conducted in Turkey (ratio of 1 : 1.47) [13] and Nepal (ratio of 1:2) [14] while in the study conducted by Banday et al. [15], male : female ratio was 1: 3. 2. This may be due to increased incidence of suicide in females being more sensitive and can be affected easily by emotional conflicts specially those more than 14 years.

Approximately two thirds of poisoned cases were from rural areas $(67.5 \%)$ and this was consistent with other studies [16, 17]. As our country is dependent mainly on agriculture, pesticides are readily available at home and easily accessible by children, thereby exposing them to unintentional poisonings. Additionally, older children may work with parents in the farms, and are therefore more susceptible to dermal contact and inhalation of organophosphates used for pest control.

In agreement with Banday et al [15], miosis was the most frequently encountered sign in our study $(100 \%)$ followed by respiratory symptoms while in Banerjee et al., study [18] miosis (91.94\%) was the most common sign and vomiting was the most common symptom (85.02\%). Variation of clinical presentation from one to
Table 3 Clinical and therapeutic features of studied cases

\begin{tabular}{|c|c|}
\hline Variable & $\begin{array}{l}\text { Total patients } \\
(n=108) \text { n (\%) }\end{array}$ \\
\hline \multicolumn{2}{|l|}{ Severity of poisoning } \\
\hline Mild (grade 1) & $19(17.5 \%)$ \\
\hline Moderate (grade 2) & $46(42.5 \%)$ \\
\hline Severe (grade 3) & $43(40 \%)$ \\
\hline \multicolumn{2}{|l|}{ Time to presentation } \\
\hline$\leq 6 h$ & $43(40 \%)$ \\
\hline$>6 \mathrm{~h}$ & $65(60 \%)$ \\
\hline \multicolumn{2}{|l|}{ Consciousness and brain injury status } \\
\hline Conscious & $42(39 \%)$ \\
\hline Mild brain injury (GCS 13-15) & $24(22.2 \%)$ \\
\hline Moderate brain injury (GCS 9-12) & $13(12 \%)$ \\
\hline Sever brain injury (GCS $\leq 8)$ & $29(26.8 \%)$ \\
\hline \multicolumn{2}{|l|}{ Common clinical manifestations at presentation } \\
\hline Miosis & $108(100 \%)$ \\
\hline Respiratory distress & $84(77.7 \%)$ \\
\hline Vomiting & $47(43.5 \%)$ \\
\hline Bradycardia & $36(33.3 \%)$ \\
\hline Sweating & $17(15.7 \%)$ \\
\hline Convulsion & $15(13.8 \%)$ \\
\hline Muscle weakness & $12(11.1 \%)$ \\
\hline Fasciculations & $9(8 \%)$ \\
\hline \multicolumn{2}{|l|}{ Complications } \\
\hline Respiratory failure & $14(13 \%)$ \\
\hline Aspiration pneumonia & $5(4.6 \%)$ \\
\hline Septicemia & $3(2.8 \%)$ \\
\hline Acute renal failure & $1(0.9 \%)$ \\
\hline \multicolumn{2}{|l|}{ Use of atropine (all cases) } \\
\hline Initial at emergency & $0.2-0.8 \mathrm{mg}$ \\
\hline Cumulative dose & $1.33 \pm 0.52 \mathrm{mg}$ \\
\hline \multicolumn{2}{|l|}{ Use of pralidoxime (9 cases) } \\
\hline Initial at emergency & $0.5-1 \mathrm{~g}$ \\
\hline Cumulative dose & $13.95 \pm 5.04 \mathrm{~g}$ \\
\hline Need for Mechanical ventilation & $14(13 \%)$ \\
\hline Decontamination (charcoal \&gastric lavage) & $39(36.1 \%)$ \\
\hline
\end{tabular}

GCS Glasgow coma scale

another study may be related to the type OP involved, the quantity absorbed, and route of exposure.

The mortality following OP poisoning varies from 4$30 \%$ [19]. Mortality rate in our study was $5.5 \%$ which was comparable to a previous study done in Nepal (5.9\%) [17]. Causes of death in our cases were related to respiratory failure in 4 cases and aspiration pneumonitis complicated bysepticemia in two. Delayed presentation to hospital owing to difficult transport from rural areas 
Table 4 Clinical and laboratorial variables between survivors and non survivors

\begin{tabular}{|c|c|c|c|}
\hline Variables & $\begin{array}{l}\text { Survivors } \\
(n=102)\end{array}$ & $\begin{array}{l}\text { Non survivors } \\
(n=6)\end{array}$ & $P$ value \\
\hline Age (years) & $8.09 \pm 4.20$ & $4.51 \pm 1.04$ & $<0.05$ \\
\hline Duration of hospital stay (days) & $3.43 \pm 1.72$ & $5.16 \pm 1.78$ & $<0.05$ \\
\hline Time to presentation (hours) & $5.91 \pm 3.05$ & $8.66 \pm 3.32$ & $<0.05$ \\
\hline Glasgow coma scale & $9.74 \pm 1.26$ & $7.50 \pm 0.83$ & $<0.001$ \\
\hline Need for mechanical ventilation & 9/102 (8.8\%) & $5 / 6(83.3 \%)$ & $<0.001$ \\
\hline Start treatment before arrival & $26(25.5 \%)$ & $0 / 6(0 \%)$ & $<0.001$ \\
\hline \multicolumn{4}{|l|}{ Type of poisoned organophosphate } \\
\hline Malathion (81 cases) & $78(96.3 \%)$ & $2(3.7 \%)$ & \multirow[t]{4}{*}{$<0.001$} \\
\hline Chlorpyrifos (9 cases) & $7(77.8 \%)$ & $2(22.2 \%)$ & \\
\hline Diazinon (6 cases) & $5(83.3 \%)$ & $1(17.7 \%)$ & \\
\hline Unknown (12 cases) & $11(91.6 \%)$ & $1(8.4 \%)$ & \\
\hline Hemoglobin, g/dL & $9.99 \pm 1.59$ & $9.56 \pm 1.67$ & NS \\
\hline Leucocytes, $\times 10^{3} / \mathrm{mL}$ & $10.32 \pm 3.09$ & $14.66 \pm 3.14$ & $<0.01$ \\
\hline Platelets $\times 10^{3} / \mathrm{mL}$ & $308.35 \pm 89.98$ & $340.88 \pm 74.61$ & NS \\
\hline $\mathrm{PaO} 2 \mathrm{mmHg}$ & $97.23 \pm 11.31$ & $83.33 \pm 4.41$ & $<0.01$ \\
\hline $\mathrm{PaCO} 2 \mathrm{mmHg}$ & $40.18 \pm 3.86$ & $40.66 \pm 4.27$ & NS \\
\hline Cumulative dose of atropine (mg) & $1.31 \pm 0.52$ & $1.61 \pm 0.44$ & NS \\
\hline Cumulative dose of pralidoxime (gm) & $9.65 \pm 3.68$ & $17.4 \pm 2.70$ & $<0.01$ \\
\hline
\end{tabular}

$\mathrm{PaO} 2$ Partial pressures of oxygen, $\mathrm{PaCO} 2$ Partial pressures of carbon dioxide; $P$ value $<0.05$ is significant; NS Non significant

particularly for cases poisoned at night, delayed endotracheal intubation and improper preliminary resuscitation measures aggravate the problem. Some cases brought to our centers after ingestion of large amount of water and suffered repeated aspiration and severe electrolyte disturbance. Our finding of frequent deaths in younger than older children may be related to their small body mass giving higher body surface area in relation to small weight and therefore, more exposure. In general, pediatric studies report frequency of unintentional ingestions and tend to have a lower mortality than adult studies. As reported by Reddy et al. [20], and Ali et al [21] studies, adults are exposed to higher doses with intentional ingestions so carry higher mortality. The mean time to presentation from toxic exposure to hospital presentation in our study was significantly higher in non survivors. In concordance with our notice, the study done by El- Naggar et al. [22], estimated average time for admission to the emergency department ranging from one to 6 hours, and they concluded that rapid hospital admission was a vital factor for the low mortality rate of their studied cases. In the current study, $61 \%$ presented with altered sensorium; of them $26.8 \%$ were in deep coma with GCS $\leq$ 8.Levy-Khademiet al [23], reported neurological manifestations as the major clinical manifestation following organophosphate exposure in children and noticed coma and/or seizures in (71\%) of studied cases. It was documented that OPC induce neuropathy leading to hypoperfusion in the central nervous system and this with other hemodynamic

Table 5 Multiple linear regression analysis of independent risk factors of mortality

\begin{tabular}{|c|c|c|c|c|c|}
\hline Variable & $\beta$ & Standard error & Hazard ratio & Confidence Interval 95\% & $P$ Value \\
\hline Time to presentation (hours) & -0.127 & 0.030 & 0.881 & $0.831-0.934$ & $<0.001$ \\
\hline Glasgow coma scale & 0.036 & 0.006 & 1.037 & $1.025-1.048$ & $<0.001$ \\
\hline Need for MV & 0.158 & .041 & 1.314 & $1.219-1.436$ & $<0.001$ \\
\hline Duration of hospital stay (days) & 0.008 & 0.019 & 1.008 & $0.971-1.047$ & NS \\
\hline Leucocytes, $\times 10^{3} / \mathrm{mL}$ & 0.169 & .057 & 1.534 & $1.461-1.873$ & $<0.001$ \\
\hline $\mathrm{PaO} 2 \mathrm{mmHg}$ & -0.033 & 0.008 & 1.033 & $1.017-1.049$ & $<0.001$ \\
\hline Cumulative atropine dose (mg) & 0.003 & 0.002 & 1.003 & $0.998-1.007$ & NS \\
\hline Cumulative pralidoxime dose (gm) & 0.187 & 0.039 & 1.205 & $1.115-1.302$ & $<0.001$ \\
\hline
\end{tabular}

MV Mechanical ventilation, $\mathrm{PaO} 2$ Partial pressures of oxygen, $P$ value significant $<0.05$; NS Non significant 
abnormalities causes the GCS value to decrease. Low values of GCS have the potential for development of respiratory failure and worse prognosis [24]. Mortality was also high in patients who required mechanical ventilation than others. Fourteen patients were ventilated; of them $35.7 \%$ were expired and most of them required MV more than 7 days (28.7\% of 35.7\%). These patients developed lung complications due to prolonged mechanical ventilation as nosocomial infections. Comparable to our study, $17 \%$ of organophosphate poisoned children in El nagger et al., study [22] developed respiratory failure and necessitated endotracheal intubation and mechanical ventilation; $66.6 \%$ of them died. Deterioration of respiratory function was related to excessive secretions, aspiration pneumonia and septicemia complicating adult respiratory distress syndrome [4]. Meticulous monitoring during transport and prompt detection of poor gag reflex could reduce the incidence of aspiration pneumonia. Early recognition of respiratory failure, swift endotracheal intubation, and mechanical ventilation are life-saving measures in severe organophosphate poisoning [25]. In our study, not all poisoned cases with GCS $\leq$ 8 had been ventilated due to 2 causes. The first is the limited intensive care beds and expensive resources in our locality that necessitate judicious use. The second is some studies that suggested safer approach to observe poisoned patients with decreased consciousness, even if they have a GCS $\leq 8$ without intubation. In Duncan and Thakore study [26], none of poisoned patients with GCS of 8 or less suffered aspiration or required intubation. Also, in Sauter et al. [27], study, more than two thirds of intoxicated patients with GCS $\leq 8$ were not intubated without any severe complications.

Leucocytosis was significantly higher in non survivors agreeing with several previous studies [28, 29]. Kumar et al. [28], in a prospective observational study found that levels of leucocytes during admission can be used as a prognostic marker in patients with OP poisoning and Tang et al. [29], had also confirmed the diagnostic value of leucocytes in OP poisoning. We detected significantly higher rate of hypoxemia and diminution of Pao 2 in non survivors. Respiratory failure was reported to occur in $24-66 \%$ of OP poisoning [30-32]. Muscarinic effects of salivation, rhinorrhea, bronchorrhea and bronchospasm and predispose to hypoxemia and increased work of breathing. Nicotinic effects result in muscle weakness and paralysis and contributed to hypercapnic respiratory failure [33]. Regarding type of organophosphate compounds incriminated in the poisoning acts, malathion was the most frequent in our study due to its common use as the least toxic and being an ingredient in local therapies regulated by the United States Food and Drug Administration (FDA) to control head lice [34]. Human have greater carboxylesterase activity relative to levels in insects hence, have the ability to degrade malathion more quickly than it is oxidized to the malaoxon form. This accounts for the relatively low toxicity of malathion [35, 36]. Bioactivation of malathion to the active metabolite malaoxon is necessary to execute its toxic effect through oxidative sulfuration. Toxicity of malaoxon is approximately 22 times more than the parent malathion after ingestion and 33 times more toxic by all other routes of exposure [37]. While we detected malathion as the least lethal organophosphate compound (3.7\%), we found chlorpyrifos as the most lethal (22. 2\%) agreeing with Liu et al. [38], study where the mortality rate by chlorpyrifos was (15\%).

Whatever the situation, diagnosis of OP poisoning must not be delayed and must be picked up basically by history taking, characteristic clinical manifestations, garlic smell of pesticides [39], characteristic clinical presentation, atropine test and decreased serum levels of cholinesterase levels if attainable. In our current study, serum cholinesterase activity was not measured due to non-availability in our center owing to financial impact. However, as a principle, treatment of OP poisoning should be started urgently without waiting the results of serum cholinesterase levels. Rescue workers in primary health institutions should be well trained for provision of emergency services and general population should be informed in regular programs about safer use of pesticides. Moreover, policy towards development of effective and less-toxic pesticides should be warranted.

The strength of this study includes being one of the few studies that give attention to risk factors of mortality due to organophosphates poisoning in Egypt. In addition, this study was a prospective one, so it avoided errors of dependence on previous records and unavailability of some needed data. The most important limitation of this study is the small sample size of studied children. Another important limitation is the lack of cholinesterase activity estimation in our localities whereas the financial matter was an obstacle.

\section{Conclusion}

This study concluded that time consumed till presentation to hospital, low GCS, need for MV, leucocytosis and decreased $\mathrm{PaO} 2$ and increased cumulative dose of pralidoxime were independent risk factors of mortality.

\section{Abbreviations}

Ach: Acetylcholine; AChE: Acetylcholinesterase; GCS: Glasgow coma scale; MV: Mechanical ventilation; OP: Organophosphates poisoning; OPCs: Organophosphate Compounds; PaCO2: Partial pressures of carbon dioxide; PaO2: Partial pressures of oxygen 


\section{Supplementary Information}

The online version contains supplementary material available at https://doi. org/10.1186/s12887-021-02563-w.

Additional file 1:. Questionnaire for data collection.

\section{Acknowledgments}

Not applicable.

\section{Authors' contributions}

KA designed and performed the study, analysed data and co-wrote the paper. EF shared in data collection, analysis and interpretation. YF shared in study design, critical revision of the article and co-wrote the paper. All authors read and approved the final manuscript.

\section{Funding}

This study received no fund from any institution.

\section{Availability of data and materials}

The datasets used and analysed during the current study are available from the corresponding author on reasonable request.

\section{Declarations}

\section{Ethics approval and consent to participate}

This study was approved by ethical committee of South valley university and consent was taken from parents for participation in the study.

\section{Consent for publication}

Not applicable.

\section{Competing interests}

The authors declare that they have no competing interests

\section{Author details}

'Department of Pediatrics, Qena Faculty of Medicine, South Valley University, Qena, Egypt. ${ }^{2}$ Department of Pediatrics, Faculty of Medicine, Assiut University, Assiut, Egypt.

\section{Received: 11 August 2020 Accepted: 19 February 2021}

\section{Published online: 26 February 2021}

\section{References}

1. Dharmani C, Jaga K. Epidemiology of acute organophosphate poisoning in hospital emergency patients. Rev Environ Health. 2005;20(3):215-32. https:// doi.org/10.1515/reveh.2005.20.3.215

2. Tsai JR, Sheu CC, Cheng MH, Hung JY, Wang CS, Chong IW, Huang MS, Hwang JJ. Organophosphate poisoning: 10 years of experience in southern Taiwan. Kaohsiung J Med Sci. 2007;23(3):112-9. https://doi.org/10.1016/S1 607-551X(09)70385-7.

3. Colović MB, Krstić DZ, Lazarević-Pašti TD, Bondžić AM, Vasić VM Acetylcholinesterase inhibitors: pharmacology and toxicology. Curr Neuropharmacol. 2013;11(3):315-35. https://doi.org/10.2174/1570159X11311 030006

4. Sungur M, Guven M. Intensive care management of organophosphate insecticide poisoning. Crit Care. 2001;5:211-5. https://doi.org/10.1186/ cc1025.

5. Kumar SV, Fareedullah MD, Sudhakar Y, Venkateswarlu B, Kumar EA. Current review on organophosphorous poisoning. Arch Appl Sci Res. 2010;2:199-215.

6. Munidasa UA, Gawarammana IB, Kularatne SA, Kumarasiri PV, Goonasekera CD. Survival pattern in patients with acute organophosphate poisoning receiving intensive care. J Toxicol Clin Toxicol. 2004;42:343-7. https://doi. org/10.1081/clt-120039539.

7. Wadia RS. Treatment of organophosphate poisoning. Indian J Crit Care Med 2003;17:85-7.

8. Eddleston M, Chowdhury FR. Pharmacological treatment of organophosphorus insecticide poisoning: the old and the (possible) new. $\mathrm{Br}$ J Clin Pharmacol. 2016;81:462-70.
9. Yanagisawa N, Morita H, Nakajima T. Sarin experiences in Japan: acute toxicity and long-term effects. J Neurol Sci. 2006;249:76-85. https://doi.org/1 0.1016/j.jns.2006.06.007.

10. Bardin PG, Van Eeden SF, Moolman JA, Foden AP, Joubert JR. Organophosphate and carbamate poisoning. Arch Intern Med. 1994;154 1433-41 PMID: 8017998.

11. Fleming LE, Gomez-Marin O, Zheng D, Ma F, Lee D. National Health Interview Survey mortality among US farmers and pesticide applicators. Am J Ind Med. 2003;43:227-33. https://doi.org/10.1002/ajim.10162.

12. London L, Flisher AJ, Wesseling C, Mergler D, Kromhout H. Suicide and exposure to organophosphate insecticides;cause or effect? Am J Ind Med. 2005;47(4):308-21. https://doi.org/10.1002/ajim.20147.

13. Rehiman S, Lohani SP, Bhattarai MC. Correlation of serum cholinesterase level, clinical score at presentation and severity of organophosphorous poisoning. J Nepal Med Assoc. 2008;47:47-52 PMID: 18709030.

14. Shivakumar S, Rajan SK, Madhu CR, Doss P, Pasupathy S, Dhandapani E. Profile of acute poisoning in Chennai: a two year experience in Stanley medical college and hospital (1999-2000). J Assoc Physicians India. 2002;50:206.

15. Banday TH, Tathineni B, Desai MS, Naik V. Predictors of morbidity and mortality in Organophosphorus poisoning: a case study in rural Hospital in Karnataka, India. N Am J Med Sci. 2015;7(6):259-65. https://doi.org/10.4103/1 947-2714.159331.

16. Mishra A, Shukla SK, Yadav MK, Gupta AK. Epidemiological Study of Medicolegal Organophosphorus Poisoning in Central Region of Nepal. J Forensic Res. 2012;3:9-18. https://doi.org/10.4172/2157-7145.1000167.

17. Koirala DP, Rao KS, Malla KK, Malla T. A Study of Clinical Features, Management and Outcome of Organophosphate and Carbamate Poisoning in Children. J Nepal Paediatr Soc. 2013;33(2):85-90. https://doi.org/10.3126/ jnps.v33i2.7799.

18. Banerjee I, Tripathi SK, Roy AS. Clinico-epidemiological profile of poisoned patients in emergency department: A two and half year's single hospital experience. Int J Crit IIIn Inj Sci. 2012:4(1):14-7. https://doi.org/10.4103/22295151.128007.

19. Yamashita M, Yamashita M, Tanaka J, Ando Y. Human mortality in organophosphate poisoning. Vet Hum Toxicol. 1997;39:84-5 PMID: 9080632

20. Reddy BS, Skaria TG, Polepalli S, Vidyasagar S, Rao M, Kunhikatta V, Nair S, Thunga G. Factors associated with outcomes in organophosphate and carbamate poisoning: a retrospective study. Toxicol Res. 2020:36:257-66. https://doi.org/10.1007/s43188-019-00029-x.

21. Ali M, Kumar $V$, Ahmed S, Iram S, Ahmed S, Abdul Sattar R. Mortality among organophosphate poisoning patients presenting with low glasgow coma scale score at a tertiary care hospital. Professional Med J. 2020;27(10):218792. https://doi.org/10.29309/tpmj/2020.27.10.4383.

22. El-Naggar AER, Abdalla AS, El-Sebaey AS, Badawy SM. Clinical findings and cholinesterase levels in children of organophosphates and carbamates poisoning. Eur J Pediatr. 2009;168(8):951-6. https://doi.org/10.1007/s00431008-0866-z.

23. Levy-Khademi F, Tenenbaum AN, Wexler ID, Amitai Y. Unintentional organophosphate intoxication in children. Pediatr Emerg Care. 2007:23(10): 716-8. https://doi.org/10.1097/pec.0b013e318155ae0e PMID: 18090104.

24. Grmec S, Mally S, Klemen P. Glasgow coma scale score and QTC interval in the prognosis of organophosphate poisoning. Acad Emerg Med. 2004;11: 925-30. https://doi.org/10.1197/j.aem.2004.03.018.

25. Hollis GJ. Organophosphate poisoning versus brainstemstroke. Med J Aust. 1999;170:596-7.

26. Duncan $\mathrm{R}$, Thakore S. Decreased Glasgow coma scale score does not mandate endotracheal intubation in the emergency department. J Emerg Med. 2009;37(4):451-5. https://doi.org/10.1016/j.jemermed.2008.11.026.

27. Sauter TC, Rönz K, Hirschi T, Lehmann B, Hütt C, Exadaktylos AK, Müller M. Intubation in acute alcohol intoxications at the emergency department. Scand J Trauma Resusc Emerg Med. 2020;28(1):11. https://doi.org/10.1186/ s13049-020-0707-2.

28. Kumar S, Agrawal S, Raisinghani N, Khan S. Leukocyte count: a reliable marker for the severity of organophosphate intoxication? J Lab Physicians. 2018;10:185-8. https://doi.org/10.4103/JLP.JLP_100_17.

29. Tang YH, Hu LF, Hong GL, Zhong DH, Song JX, Zhao GJ, Lu ZQ. diagnostic value of complete blood count in paraquat and organophosphorus poisoning patients. Toxicol Ind Health. 2018;34:439-47. https://doi.org/10.11 77/0748233718770896.

30. Peter JV, Jerobin J, Nair A, Bennett A, Samuel P, Chrispal A, Abraham OC, Mathews KP, Fleming JJ, Oommen A. Clinical profile and outcome of 
patients hospitalized with dimethyl and diethyl organophosphate poisoning. Clin Toxicol (Phila). 2010;48:916-23. https://doi.org/10.3109/15563 650.2010.528425

31. Wang CY, Wu CL, Tsan YT, Hsu JY, Hung DZ, Wang CH. Early onset pneumonia in patients with cholinesterase inhibitor poisoning. Respirology. 2010;15:961-8. https://doi.org/10.1111/j.1440-1843.2010.01806.x.

32. Eddleston M, Mohamed F, Davies JO, Eyer P, Worek F, Sheriff MH, Buckley NA. Respiratory failure in acute organophosphorus pesticide self-poisoning QJM. 2006;99:513-22. https://doi.org/10.1111/j.1440-1843.2010.01806.X.

33. Peter JV, Sudarsan TI, Moran JL. Clinical features of organophosphate poisoning: A review of different classifcation systems and approaches. Indian J Crit Care Med. 2014;18(11):735-45. https://doi.org/10.4103/0972-522 9.144017 .

34. Environmental Protection Agency (EPA). Reregistration Eligibility Decision (RED) for Malathion. EPA 738-R-06-030; US, Office of Prevention, Pesticides, and Toxic Substances, Office of Pesticide Programs. Washington, DC: US Government Printing Office; 2006.

35. Costa LG. In: Klaassen CD, editor. Toxic effects of pesticides. Casarett and Doull's Toxicology: The Basic Science of Poisons, 7th ed. New York: McGraw Hill Medical; 2008. p. 883-930.

36. Malathion: Revised human health risk assessment for the reregistration eligibility decision document (RED); EPA-HQ-OPP-2004-0348-0057; U.S. Environmental Protection Agency, Office of Prevention, Pesticides and Toxic Substances, Office of Pesticide Programs, U.S. Government Printing Office: Washington, DC, 2006., in National Pesticide Information Center. (n.d.). Malathion technical fact sheet. Retrieved from NPIC website: npic.orst.edu/fa ctsheets/malatech.pdf.

37. USEPA: Revised Reregistration Eligibility Decision (RED) for Malathion; EPA 738-R-06-030; U.S. Environmental Protection Agency, Office of Prevention, Pesticides and Toxic Substances, Office of Pesticide Programs, U.S. Washington DC: Government Printing office; 2009.

38. Liu HF, Ku CH, Chang SS, Chang CM, Wang IK, Yang HY, et al. Outcome of patients with chlorpyrifos intoxication. Hum Exp Toxicol. 2020;39(10):1291300. https://doi.org/10.1177/0960327120920911 Epub 2020 Apr 27.

39. Melum MF. Emergency. Organophosphate toxicity. Am J Nurs. 2001;101(5): 57-8.

\section{Publisher's Note}

Springer Nature remains neutral with regard to jurisdictional claims in published maps and institutional affiliations.

Ready to submit your research? Choose BMC and benefit from:

- fast, convenient online submission

- thorough peer review by experienced researchers in your field

- rapid publication on acceptance

- support for research data, including large and complex data types

- gold Open Access which fosters wider collaboration and increased citations

- maximum visibility for your research: over $100 \mathrm{M}$ website views per year

At $\mathrm{BMC}$, research is always in progress.

Learn more biomedcentral.com/submissions 